University of Wollongong

Research Online

Faculty of Business - Papers (Archive)

Faculty of Business and Law

2012

Exploring hegemonic change in China: a case of accounting evolution

Lina $\mathrm{Xu}$

University of Wollongong, Ix992@uowmail.edu.au

Corinne L. Cortese

University of Wollongong, corinne@uow.edu.au

Ying Zhang

University of Wollongong, eagle@uow.edu.au

Follow this and additional works at: https://ro.uow.edu.au/buspapers

Part of the Business Commons

Research Online is the open access institutional repository for the University of Wollongong. For further information contact the UOW Library: research-pubs@uow.edu.au 


\title{
Exploring hegemonic change in China: a case of accounting evolution
}

\begin{abstract}
This paper uses Gramsci's concept of hegemony to investigate periods of leadership and accounting change throughout Chinese history. In particular, this paper provides an understanding of how accounting systems have changed across four distinct periods of hegemonic leadership in China: the Confucian tradition, the rise of the socialist system followed by the Cultural Revolution under the Maoist era, and the move towards the socialist-market system in the Dengist era. This paper shows how political leaders in these different time periods effectively achieved leadership by destroying an existing hegemony, creating a new ideology, and implanting this into people's daily lives in order to successfully mobilise their ideological systems. Consistent with changes in leadership, Chinese accounting systems are shown to have responded to hegemonic shifts across these periods. This paper contributes to understandings of Gramsci's concept of hegemony, explanations of, and motivations for, accounting change, and provides an insight into the evolution of accounting systems throughout time in the context of China.
\end{abstract}

\section{Keywords}

Accounting Systems, China, political ideology, Confucianism, Hegemony

Disciplines

Business

\section{Publication Details}

Xu, L., Cortese, C. L. \& Zhang, Y. (2012). Exploring hegemonic change in China: a case of accounting evolution. Accounting and Finance Association of Australia and New Zealand Conference (pp. 1-22). Melbourne, Australia: The Accounting and Finance Association of Australia and New Zealand. 


\title{
Exploring Hegemonic Change in China: A Case of Accounting Evolution
}

\begin{abstract}
This paper uses Gramsci's concept of hegemony to investigate periods of leadership and accounting change throughout Chinese history. In particular, this paper provides an understanding of how accounting systems have changed across four distinct periods of hegemonic leadership in China: the Confucian tradition, the rise of the socialist system followed by the Cultural Revolution under the Maoist era, and the move towards the socialist-market system in the Dengist era. This paper shows how political leaders in these different time periods effectively achieved leadership by destroying an existing hegemony, creating a new ideology, and implanting this into people's daily lives in order to successfully mobilise their ideological systems. Consistent with changes in leadership, Chinese accounting systems are shown to have responded to hegemonic shifts across these periods. This paper contributes to understandings of Gramsci's concept of hegemony, explanations of, and motivations for, accounting change, and provides an insight into the evolution of accounting systems throughout time in the context of China.
\end{abstract}

Key words: Accounting Systems; China; political ideology; Confucianism; Hegemony. 


\section{Introduction}

Many existing studies have reviewed Chinese accounting systems under the impact of different economic structures (Child and Lu 1990; Winkle et al. 1994; Tang 1997; Bing 1998; Chan and Rotenberg 1999; Lin et al. 2001; You and Luo 2009). Few studies, however, have looked at the impact of political and cultural ideologies on accounting systems. A notable exception is a study by Ezzamel et al. (2006), which examined accounting systems change under Maoism and Dengism in China. The ideologies put forward by Mao, such as class struggle, central planning, and public ownership were analysed and explained as the reason why the Maoist accounting systems were fundamentally different to those prevalent in capitalist societies (Ezzamel et al. 2006). However, it was shown that under Deng, new ideologies, such as economic development, marketisation, and mixed-ownership were diffused, and correspondingly new accounting systems were created to harmonise Chinese accounting with the West (Ezzamel et al. 2006).

Contributing to this field of study, this paper further explores the role of ideology in mobilising and sustaining different political hegemonies that have influenced the development of accounting at a more fundamental level. By drawing on Gramsic's theory of hegemony, this paper provides an alternative framing that explains the intrinsic link between cultural, political power and accounting systems. Gramsci's concept of hegemony was used by Yee (2009) to examine the political circumstance leading to the re-emergence of the accounting profession at the beginning of 1980s in China. Yee (2009) explained the importance of the hierarchical relationships that define Chinese social structures, and which are reinforced by Confucianism, and provided evidence that the rise of the accounting profession in the Deng era was linked to the political and ideological values espoused under his leadership. This study provides further evidence of the impact of political and cultural ideology on accounting systems in China by examining how the Confucian ideology collapsed, how accounting systems functioned and why they were suspended during the Cultural Revolution, and how new ideologies under the Dengist period helped the reestablishment of accounting systems.

The reminder of this paper is organised as follows: the next section explains Gramsci's concept of hegemony and also reviews previous literature related to this theory. Section three presents an analysis of accounting systems change in China and how these changes have aligned with important periods in hegemonic leadership. Finally, conclusions are presented.

\section{Gramsci's concept of hegemony}

\subsection{Gramsci and hegemony}

Gramsci (1891-1937) was an Italian writer, philosopher, politician and linguist as well as the founding member and onetime leader of the Communist Party of Italy (Bates 1975). After his arrest and imprisonment at the hands of the Fascist regime in 1926, Gramsci wrote his 
"Prison Notebooks" which traced his views on Italian history, nationalism, Marxist theory and critical theory (Bates 1975). Gramsci attempted to identify the relationships between political control, economic crisis, and civil society in his prison books by revising the classical Marxist role of the state in society. As a critical thinker, he rejected many mainstream ideas and believed that while an economic base is essential to produce outcomes, political and ideological concepts are ultimately decisive in decision-making (Femia 1975). Gramsci provided an insight into the historical events in different countries, and believed that humans generate and maintain their own historical process in a specific time and place (Simon 1982).

A significant contribution made by Gramsci was his development of the notion of hegemonic theory. Hegemony is particularly concerned with how dominance is established and maintained (Simon 1982). According to Gramsci, the analysis of hegemony is integrated with social, political and ideological forces (Alawattage and Wickramasinghe 2004). Williams (1960, p.587) defined hegemony as:

... an order in which a certain way of life and thought is dominant, in which one concept of reality is diffused throughout society, in all its institutional and private manifestations, informing with its spirit all tastes, morality, customs, religions and political principles, and all social relations, particularly in their intellectual and moral connotations.

Hegemony, therefore, describes the power or domination of a social group or ruling class over another insofar as it is exercised through ideas and values (Cooper 1995; Greaves 2008). Marxists initially considered the concept of hegemony in their argument for an 'inevitable' socialist revolution that would arise by the early twentieth century as a result of political leadership being overtaken by the working-class (Bates, 1975). However when this did not occur, and instead capitalism appeared to be becoming more entrenched, Gramsci sought an explanation through an extension of the way hegemony is understood. Instead of viewing the exercise of hegemonic power as a function of violence, and political and economic coercion, Gramsci suggested that hegemonic control could also be exercised ideologically, that is through the development of a hegemonic culture where the values of the ruling class became seen as the "common sense" values (Bates 1975; Goddard 2002, p.659). This development of a 'consensus culture' would help in ensuring the maintenance of the status quo rather than a revolution of the working-class against the bourgeoisie (Bates 1975).

In this way, the concept of hegemony suggests that political leadership is achieved by the consent of the led, and that diffusion and popularisation of such groups' world view is an approach to maintain the leadership (Bates 1975). The leading group obtains consensus from a majority of the population and creates conditions for the development of a strong economic base, which then provides a range of possible outcomes that can be shaped by political and ideological activity (Gramsci 1978; Goddard 2002; Lee 2009). This leading group, 
that is the hegemonic class, gains the consent of other groups by the creation and maintenance of a system of political and ideological alliances that may last for an entire historical period (Goddard 2002; Simon 1982; Spence 2009).

\subsection{Hegemonic ideology, culture and crisis}

Ideology appears as a core concept in hegemonic theory (Goddard 2002; Momin and Belal 2009). Simon (1982, p.59), for example, provides a summary of Gramsci's conception of ideology:

... ideologies have a material existence in that they are embodied in the social practices of individuals and in the institutions and organisations within which these social practices take place.

In this way, ideology may be seen from a constructionist perspective: as a means of reality creation and re-creation that occurs as practices are formed, diffused, and (re)acted upon (Greaves 2008). The organisations within which ideology diffusion takes place are also crucial to understandings of hegemony. In his Prison Notebooks, Gramsci (1971, p.31) makes particular note of the importance of the public sector: "hegemony presupposes that account be taken of the interests of the groups over which hegemony is to be exercised", such that "the leading group makes sacrifices of an economic-corporate kind" in order to maintain its hegemonic position. The provision of public services, via the public sector, has been suggested as one such sacrifice which enables the creation of "hegemonic institutions whose primary purpose is to maintain a consensus within society but also maintain the dominance of one social group" (Goddard 2002, p.659). It is through these hegemonic institutions that societal practices are developed and diffused in such a way that they become the dominant ideology; the common sense values that are shared by both the ruling and other social classes (Ezzamel et al. 2006; Goddard 2002).

Gramsci used the word "culture" to describe his understanding of ideology as a collective understanding, a shared notion of rules of conduct and behaviour (Simon 1982, p.58). Yee (2009) noted that the Chinese ruling class often placed significant importance on the diffusion of its political ideologies in order that these ideologies become part of the culture of Chinese people's daily life. Formal rules were not seen as a sufficient means of exercising power. Instead, the development of a shared culture was viewed as an effective way to facilitate and reinforce hegemony.

Contrary to Marxist views which conceive power as held by the state, Gramsci saw power as relational and introduced the concepts of 'civil society' and 'political society' to explain his understanding of power. Political society, according to Gramsci, involves the coercive relations of the state, most often exercised through legislation, and includes public service institutions such as the armed forces, government, police and the law (Gramsci 1971; Yee 2009). Civil society comprises the 'so-called private' organisations that contribute to the 
formation of social and political landscape but which are distinct from the state, such as churches, trade unions, political parties, media, and cultural associations (Gramsci 1971; Yee 2009; Goddard 2002). Gramsci's relational view of power meant that he saw political (state) power and civil (private) power as intertwined (Yee 2009). The hegemonic class exercises power over subordinate classes in the civil society through the process of consensus, while also exercising power through its prevalence in the political society (Yee 2009; Goddard 2002). Thus, there is a fundamental difference between hegemony and domination: once political power is achieved, the ruling class is able to exercise coercive power over subordinate groups and social forces, however to secure hegemony, the ruling class must maintain a system of alliances that will enable the continuation of their political and ideological domination (Yee 2009).

Hegemony is largely achieved and maintained when three social conditions reinforce each other: the material forces of a society are controlled; prevailing interests tend to harmonise with the control system; and the hegemonic system appears objective and has maintained bureaucracy (Simon 1982). Only when these factors reach alignment do the prevailing economic, social and control systems enjoy the maintenance of stability, and then, the dominant class tend to solve other conflicts by legitimising logic and legal structures (Rucki 2011). This type of system is one example of class compromise, which reinforces the dominant position through providing some benefits to subordinates classes without threatening the benefits of the control group (Rucki 2011).

Organic processes are another concept that Gramsic emphasised. They are preceded and attached to the movement of ideological and moral leadership, and also reflect human relations (Greaves 2008). In other words, humans' identity and self-consciousness are not separated from their historical stories and struggles. Intellectuals are organic only when they can be analysed in the specific organism and context (Greaves 2008). However, organic states do not always exist throughout the hegemonic period. When an organic crisis happens in a specific societal development period, the political state may consider reorganising its hegemony (Pun 1996). Different approaches may be adopted to reorganise the hegemony. For instance, an educational system changes, and provides more channels and freedom for the public to express their attitudes on public policies (Pun 1996), which aims to protect the dominant people's interest, rather than relinquishing the power of the hegemonic class. As Gramsci stated (cited in Simon 1982, pp.37-38):

A crisis occurs, sometimes lasting for decades. This exceptional duration means that incurable structural contradictions have revealed themselves (reached maturity) and that, despite this, the political process which are struggling to conserve and defend the existing structure itself are making every effort to cure them, within certain limits, and to overcome them.

Gramsci realised that an organic crisis may last for a relatively long period, which reflects the immature political leadership, not only in terms of a current economic situation, but also defending against the contemporary social system. Hence, a deep crisis needs to be cured 
by reshaping state institutional systems and forming new ideologies. However, if the power of the state is insufficient to shift the current balance, the coercive force will succeed in establishing a new hegemonic leadership (Pun 1996).

\subsection{Accounting literature: a hegemonic analysis}

Gramsci's hegemonic theory is concerned with the relationship between three sets of social relationships, namely politics, economics and ideologies (Simon 1982). It mainly focuses on how to secure political leadership by diffusing cultural ideologies and legitimising economic policies (Bates 1975; Richardson 1987). Richardson (1987) argued that class power is the main concern in the process of legitimacy, and the function of accounting is to create, distribute and maintain power. Some existing studies have used Gramsci's hegemonic perspective to explore accounting practices and theories in the aspect of legitimisation. These can be categorised into two types - hegemonic accounting profession and hegemonic regulation.

The accounting profession acts as an intermediary between the government and enterprises. Goddard (2002) explored, based on Gramsci's theory of hegemony, the main forces for the development of the UK accounting profession and accounting practices in the past 100 years. The period was divided into three distinctive stages and clearly explained by Gramsci's ideological framework linked to economic crises, class struggles and political power. Goddard (2002) demonstrated that the public accounting profession plays a significant role in reflecting and diffusing political ideologies in the UK. Similarly, in Germany, Heidhues and Patel (2011) used the hegemonic perspective to suggest that political and cultural dimensions are important to explain distinctive professional judgement, and hence, enhance the reliability and comparability of cross-border accounting reporting.

Some other studies have argued that states and nations carry out their political control via accounting regulation. Merino et al. (2010) used corporate hegemony to explain how Sarbanes-Oxley was used to promote the neoliberal agenda of deregulation and instil a market-based ideology following the US market-driven global recession. Alawattage and Wickramasinghe (2008) conducted a fieldwork in Sri Lankan tea plantations to show how political hegemony is diffused into economic enterprises. Their paper argued that accounting is used as a political tool for labour control in the third world, instead of as a tool for calculating and recording. Jayasinghe and Matilal (2011) examined the interrelationships between accounting calculations and hegemonic struggle based on a case study of premiership football in the UK. The study showed two main findings. First, accounting is used as a tool to achieve hegemonic control and maintain autonomy by the state to regulate social clubs on a macro level. Second, accounting techniques are used as a tool to achieve state macro level political economic strategies. Cooper (1995) examined the historical events in some advanced capitalist states to explain the relationship between accounting 
and the state, and recognised that accounting was a powerful force in maintaining the political leadership in the process of political struggle.

An earlier study by Alawattage and Wickramsinghe (2004) offered a theoretical analysis in Sri Lanka regarding the roles of accounting, which focused on how accounting is produced by political society, civil society and the economy throughout time, and found that accounting governance is closely linked to these historical regimes. Hence, their conclusion is that it is necessary to investigate historical regimes and that accounting governance and historical regimes are mutually integrated.

As the above discussion indicates, an important body of literature has reviewed accounting legitimacy from the perspective of hegemonic analysis by integrating the economy and the state into the theoretical framework. However, these studies have been criticised as overemphasising political leadership by ignoring the ideological aspects such as moral and intellectual leadership in accounting (Alawattage and Wickramasinghe 2008). To fill the gap, this paper explores Chinese traditional ideologies, Confucian traditional, Maoist socialist and Deng capitalist policies and their influences in the different evolution stages in Chinese accounting. More specifically, this paper will consider how political leaders have used different ideological thoughts during different periods to facilitate their hegemonies, which has led to very different accounting theories and methods being implemented in China.

\section{The evolution of accounting in China}

\subsection{Traditional Confucian hegemony: reflection on accounting systems}

\subsubsection{Contextual issues}

Traditional Chinese culture has been significantly influenced by Confucianism (Yee 2009). Confucius was a most influential Chinese philosophiser who lived approximately 2500 years ago. His thought emphasised the importance of social hierarchies and collective interest. Confucius advocated for less government influence and control, and believed that "society is not an adversary system consisting of pressure groups but a fiduciary community" (Lam 2003 , p.158). Confucianism was adopted as the official political ideology by a Chinese emperor, Liu Che, in the Han Dynasty (156 B.C. - 87 B.C.), and later was considered as an important religion of the Han Chinese, profoundly influencing China for thousands of years (Yee 2009). In Confucianism, the ultimate function of government was to maintain stable, continuous, and harmonious relations among all social members. In addition, clearly defined social hierarchy relations, such as superiors and subordinates were required (Pye 1985). From the perspective of Pye (1985), the Confucian cultural region of Asia can be seen as an early stage of the evolution concept of power which accommodates the requirements of state-building. The ideology of Confucius has served as slogan for the guidance of Chinese political life for centuries, and the sayings of Confucius have been held as the ultimate authority in society (Dawson 1981). In Confucian view, the best means of solve a conflict 
was the "middle way", that is by understanding the uncertainty and change, then making necessary adjustments in order to maintain harmony and balance (Gao and HandleySchachler 2003). Hence, when Mao came to power, the previous hegemonic conception of Confucianism had to be eliminated, in order to set up an absolute dominant position for a Maoist ideology.

Accounting systems in China can also be traced back more than two thousand years, and a relatively highly developed accounting system served financial and economic activities during that time (Van Hopean 1995; Gao and Handley-Schachler 2003). A significant influence, or perhaps even the primary influence, for Chinese accounting systems was Confucianism (Gao and Handley-Schachler 2003). Confucius was a managing officer for warehouses during the Spring and Autumn period (770 B.C. - 221 B.C.). His job was to do proper accounting, which means that receipts and disbursements of materials in the warehouse were correctly documented (SUFE and CIAD 1987). The fundamental concept of Confucian accounting was to distinguish Yi (justice) and Li (profit); he argued that nobles care about Yi, whereas common people care about Li (Van Hoepan 1995). One of Confucius' students, Mencius, was the first person who described the word "accounting" in a book, The Rites of Chou. The purpose of this book was not purely for accountants, but rather a handbook "describing government posts, official duties, and the structure of Chou government administration" (Fu 1971, p.41). It is reasonable to argue that accounting was used as a tool to achieve political control in this period. In this book, ru (receipts) and chu (disbursement) were used to describe the increase and decrease of state revenue, and later were officially adopted as bookkeeping labels (Chen 1998). This single bookkeeping method was used in both government and private economic activities to record revenue and expenses and at the end of accounting periods, all entries were summarised and balanced (Chen 1998). The formula of the three-column method, Newly received - Payment = Balance, was used and considered as a breakthrough in Chinese accounting history (Aiken and Lu 1993; Gao and Handley-Schachler 2003). This cash-based bookkeeping method was dominant in Chinese accounting systems until the 1940s (Gao and Handley-Schachler 2003). In Ancient China, the basic function of accounting was to record the flows of the Emperor's and the State's properties, and also was a kind of statistical data or part of government census (Gao and Handley-Schachler 2003). Under the impact of Confucianism, collectivism was a primary characteristic in a society, and therefore, the aim of accounting is to service the public, instead of calculating profits and wealth for individuals. Government accounting officially emerged in China during the western Chou dynasty (1066 B.C. to 771 B.C.) (Fu 1971; Gao and Handley-Schachler 2003). The government constituted six officials, namely Heaven, Earth, Spring, Summer, Autumn, and Winter during that period. The official of Heaven was responsible for the management of government properties, financial management and government accounting (Gao and Handley-Schachler 2003). Under the Heaven, the controller general was responsible for financial management, government revenue collections and control of expenditures (Aiken and Lu 1993). Heaven normally used a budget 
as a means of financial control, which also delegated authority and built responsibility and accountability (Fu 1971). Once the general decisions were made, the controller general was carried the details of the budget (Fu 1971). Another important event in Chou dynasty was the use of financial reports. At the end of the year, each department in the government was required to prepare reports for their operating sections. Some government officers acted as travelling supervisors to monitor and evaluate the quality of financial reports. After being audited, the reports were submitted to the Prime Minister, who would draft some recommendations relating to governmental policies, and finally were submitted to the Emperor (Fu 1971).

Compared to the government accounting, the private sector accounting was less advanced throughout the periods. It was argued that the collectivist ideology from Confucianism restricted the needs of accounting in private business (Gao and Handley-Schachler 2003). Another reason for the slow progress of private sector accounting can be considered, as described previously, as the Confucian attitude towards profit. In the view of Confucius, the reason for slowly progressing accounting in private sector was an attitude to maintain simplicity, because merchants were ranked as the lowest level in society and the single system bookkeeping method was sufficient for accounting records in that context (Solas and Ayhan 2007). Within the collective Confucian society, merchants, as traders of commodities rather than producers, were ranked as the lowest level in society. The agricultural producers who contributed to the collective society, rather than profited from it, were important in the ancient economy. There was a desire to maintain simplicity in record-keeping and a single entry bookkeeping method was considered sufficient for accounting records in this context (Solas and Ayhan 2007). As shown, the Confucian accounting concept influenced accounting practices in China for thousands of years in different aspects, such as bookkeeping methods, accounting information, accounting regulations, government and private accounting (Gao and Handley-Schachler 2003).

From the time of the First Opium War (1840), China became a semi-colonial, semi-feudal society, and western bookkeeping methods slowly emerged in public and private enterprises. The traditional Confucian accounting systems were still prevailing and coexisting with western countries accounting in the late nineteenth and early twentieth century (Ezzamel et al. 2006; Solas and Ayhan 2007). Based on a suggestion from Confucius, the focus of accounting is to convey customs and traditional practices, the previous form and structure were considered sufficient and it was not deemed necessary to invent new procedures (Bloom and Solotko 2003). Prior to 1911, Chinese accounting systems were dominated by a single entry record, or named cash-based record method, which was based on the movement of money or physical goods. Following by the revolution in $1911^{1}$, western accounting and auditing theories were officially brought to China (Chan and Rotenberg 1999). In the early 1920s, the increasingly number of accounts received

\footnotetext{
${ }^{1}$ The traditional, Confucian-influenced China ended, at least officially, in 1911: the empire was demolished, along with all the traditional political principles, laws, customs, and morality (Schoppa 2011, p.142).
} 
accounting education from western countries returned to China, and double-entry bookkeeping method was used by many companies. The western accounting systems were dominant in Chinese companies until 1949, the establishment of the People's Republic of China (Chan and Rotenberg 1999).

\subsubsection{Socialist hegemony in the People's Republic of China: a case in accounting systems}

Mao Zedong started a completely different political regime in China after the Chinese Communist Party (CCP) took over the power in 1949(Chen 2007). Maoist thought exhibited the dominant aims of new China: Marxism, anti-capitalism and anti-socialistic revisionism. Combining the dual aims of eliminating the political culture that had been dominant over thousands of years, and establishing a new culture in society, the communist leaders sought an efficient approach which has been fundamentally shaped by German Marxist philosophy.

According to Simon (1982), the basic premise for establishing a hegemonic class is that it is a process of political and ideological struggles, and new power is secured via not force alone, but also by ideas. Gramsci also suggested that a hegemonic class obtains significant class domination through the consent of subordinate classes, and gets the consent of minorities through armed force (Greaves 2008; Loftus and Lumsden 2008). Mao used these discourses to create an environment to influence people's thinking, which helped establish the ideology he wanted. For example, the famous saying, Bai hua qi fang, bai jia zheng ming (let a hundred flowers bloom, let a hundred schools of thought contend), was from Mao and was frequently used by Mao in his public speech. This type of discourse was used to encourage intellectuals to discuss the country's problems including political policies. This strategy helped diffuse political and government policies into people's everyday life, and the power of language was used to construct the process of social control (Yee 2009).

In Mao's era, accounting in China was characterised by ensuring accountability for the macro-economic control of government, which was similar to the Confucian accounting concept (Bloom and Solotko 2003). However, In Mao's speech, he advocated that Confucius was a capitalist, and hence, the believers of Confucius were condemned as capitalists. In Mao's (1940 cited in Zhang and Schwartz 1997, p.195) "On New Democratism", he wrote:

Those who worship Confucius and advocate reading the classic of Confucianism stand for the old ethics, old rites and old thoughts against the new culture and new thought...As imperialist culture and semi-feudal culture serve imperialism and the feudal class, they should be eliminated.

Given the influence of Confucianism, the important task was to eliminate it in the common culture of China, and then to propagate the political ideologies and agendas of Communist leaders. Additionally, Confucius favoured less rather than heavy government influence and control, the accounting and accounting regulation setting was totally controlled by 
government, and also government as a principle user of accounting reports. The previous accounting systems were suspended when the CCP was established in 1949 and the discussion of accounting systems became one of the focuses for the new Chinese economy (Bloom and Solotko 2003). The new accounting systems were expected to reflect the new political ideology of communist China, and must differ from the capitalist accounting in the West (Chen 1998).

In the process of pursuing a new hegemony, Gramsci believed that there are three steps to achieve the final hegemony: consciousness of common interest from a professional group, spreading this consciousness in all member of class, and forming hegemony (Simon 1982). This process of hegemony was shown in the reform of accounting systems in China during the Mao's regime. The consent of evil capitalist accounting has been recognised by leading accounting scholars through public discourses, and later, rejecting accounting systems that were adopted by capitalist societies during the time (Ezzamel et al. 2006).

Few scholars, such as Tao De (1951), claimed that accounting is a neutral technique, free of class struggle, but their opinion was strongly criticised by many others. For instance, Xin and Huang (1951) argued that accounting is an administrative and management tool, and it is different in different societies, which means that capitalist accounting is definitely not suitable for the socialist economy in China (Xin and Huang 1951). The accounting equation, Asset - Liability $=$ Equity, serves capitalist producers and purely benefits capitalists (Chen 1951 cited in Han 2009, p.206). Moreover, the reliability of western countries accounting systems was questioned in this debate. Xin and Huang (cited in Ezzamel et al. 2006, p.678) stated that:

...in capitalist accounting theory, asset valuation principles are designed to mask facts the interest of capitalists: if a high profit is desired, assets are valued high whereas if a reduced profit is desired, assets are valued low.

However, from Gramsci's view, intellectual and moral reform is not easy to complete. It requires a unique example from any country and contributions made by different social movements (Simon 1982). In the Chinese context, from the time that Marxism was introduced to China in 1917, Mao believed it was the only way to guide the development of China. Marxism profoundly influenced Chinese society during the time and it was also recognised as a significant influence on Chinese accounting, including accounting concepts and principles (Van Hopean 1995, p.363). Identical to the Soviet Union, the accounting system in China was characterised as state or fund accounting (Gao and Handley-Schachler 2003; Ezzamel et al. 2006). In this era, accounting within a socialist economy was defined as:

one of the means of dealing with economic management under a socialist system. It is an approach through recording and examining in terms of money the supervision and evaluation of units, (e.g. enterprises, non-business units, public organizations, etc.) economic activities and financial situation in the processing of socialist expanded reproduction (Tan Hui 1963 cited in Liu and Eddie 1995, p.143). 
Accounting was a tool for helping government economic planning and allocation of funds to different enterprises. In this new set of accounting systems, a different debt-credit bookkeeping technique was used in government accounting with an accounting equation: Fund Sources $=$ Fund Application (Aiken and Lu 1993). The main purpose of accounting was to facilitate the state control over the means of production, and this Soviet Union style accounting was regarded as the best in the world by Chinese accounting academics (Zhang 2005).

\subsection{Organic crisis and the impact on the accounting systems}

In Gramsci's view, hegemony is not to be there all the time, but has to be continually fought for afresh (Simon 1982). According to Simon (1982), an organic crisis may happen in a specific social development period, and reshape its hegemony. China was in a difficult situation from 1962, the relationship between China and the Soviet Union was broken in 1962, and a cool relationship with the United Stated still existed. Lacking support from the Soviet Union, and suffering an economic crisis caused by the Great Leap Forward, political power was threatened during this period.

Gramsci believed that such a crisis may continue for decades, with this exceptional duration indicating that "incurable structural contradictions have revealed themselves", and that the political forces are "struggling to conserve and defend the existing structure" (Simon 1982, p.38). The Cultural Revolution began in 1966 and was followed by ten years of social chaos in China. The stated purpose of the Cultural Revolution was to eliminate traditional Chinese culture, but the real purpose was to reinforce Mao's political ideology (Chiapello and Ding 2004). Decisions about the Cultural Revolution by the Central Committee of the CCP were expressed as follows: this revolution is to fight against the power of capitalism, to criticize the capitalist reactionary academic authorities, and the ideologies of bourgeoisie and exploiting class, and at the same time reform education, literature and art, so as to consolidate and develop the socialist system (Zhang 2005). Confucius was regarded as a problematic inheritance, and his ideology was seen as needing to be totally rejected. The dominant idea of the Cultural Revolution was a campaign against the four 'olds': include old thought, old culture, old tradition and old custom.

During the Cultural Revolution, Confucianism was categorized as a symbol of capitalism. Advocates of Confucianism, such as Lin Biao and Liu Shaoqi, were criticized by official newspaper, such as Guang Min Daily (on 6 December 1976), for trying to use Confucianism to restore capitalism. The ideology of Confucianism was totally rejected by the major Chinese official newspaper, People's Daily, Red Flag, and Liberation Army Daily, on 1 January 1974:

The struggle between the proletariat and the bourgeoisie in political ideology is a long, complicated and sometimes acute struggle...we should continue to criticize the worship of Confucianism (cited in Yan and Gao 1996, p.430). 
Wide criticism of Confucius was raised at the national level, which indicated that antiConfucian culture was being successfully established in Chinese society. It was viewed as important for the public to establish a new ideology consisting of Marxism-LeninismMaoism, so that everyone was encouraged to keep away from the ghost of Confucius (Yang 1974, p.66).

In the accounting discipline, the Soviet Union accounting systems were sidelined in China from 1962, following China's alienation from the Soviet Union. It was proposed to set up a completely new accounting system (Ji 2001). Taking the bookkeeping method as an example, the debit-credit double entry method was rejected, because it was used by the United States and the Soviet Union.

However, during the Cultural Revolution period (1966-1976), accounting systems were completely destroyed. Accounting was considered as a symbol of capitalism, in line with Mao's political ideology that old thought should be eradicated. One group of radicals, namely the Gang of Four, aimed to set up non-monetary economic systems in China. They believed that accounting systems perpetuated the evils associated with money and needed to be eliminated from economic activities (Van Hoepen 1995). According to Van Hoepen (1995, p.363):

During the ten years of the Cultural Revolution (1966-1976), accounting in all state and collective enterprises was terminated, the accounting people were dismissed, and the accounting departments in universities were closed. The Cultural Revolution was the most dangerous expression of discrimination against accountancy in Chinese modern history.

The Cultural Revolution ended in 1976 when Mao died. Deng took over the political power in 1978 and initiated a new era in Chinese history.

\subsection{The re-building of capitalist hegemony: a reflection on accounting}

In Gramsci's theory, during a deep or organic crisis, the efforts made by political powers cannot defend all class struggles. Hence, a new power may arise and fight against the existing political forces, and reshape the balance of the social order as well as form new ideologies (Simon 1982). If the existing hegemony is not strong enough to maintain the current position, political forces possibly build a new system by shifting to a new direction. This was manifested in China during the period.

After Mao's death, Hua Guofeng became his successor. Hua's mission was to follow Mao's will $^{2}$, and "support whatever policy decisions were made by Chairman Mao", and

\footnotetext{
${ }^{2}$ Because of Hua's insistence on following whatever policy decisions had been made by Mao, Hua and his allies became known as the "Whatever" faction (cite Meisner, p.433). Deng, on the other hand, believed that "practice is the sole criterion of truth" and Deng and his allies became known as the "Practice" faction (cite Meisner, p.433).
} 
"unswervingly follow whatever instructions were given by Chairman Mao" (Schoppa 2011, p.365). Deng, who some commentators called the "father of Chinese capitalism" (Schoppa 2011, p.366), was another important political figure in the communist party. A new political struggle started between Hua's faction and Deng's faction, which enabled a new culture and ideology to emerge in China. Hua had been following Mao's policies, making changes slowly and cautiously. In order to save the existing hegemony, Hua made every effort to cure the crisis caused by the Maoist era. The first event for the change was related to cultural and educational policies. Academic journals, and other periodicals and magazines were republished, international cultural exchanges such as translations of Western literature were encouraged, and intellectuals as released from jail and returned to cities. The second movement of changes was bringing high technology from highly advanced capitalist countries. The third change was his great ambitious effort to achieve the Four Modernizations in the aspects of agriculture, industry, national defence, and science and technology in his Ten Year Plan (between 1976 and 1985). Although Hua had embraced the programme of industrialisation in China, he was not really viewed the most qualified person to lead China towards that path (Thornton 1982). Thornton (1982, p.391) stated Deng was clearly the most qualified leader in this movement, as he "had advocated the heavy industrialization course since the mid-1950s" and had "commanded not only the expertise in that field, but also the allegiance of many trained cadres".

In order to maintain power, it's important for the leader to be seen as compatible to the mainstream ideology. Deng carefully phrased his idea to maintain the term 'socialist'. As Meisner (1999, p.439) states, if Deng simply denounced Mao as "a tyrant and usurper", he "would have cast doubt not only on the political legitimacy of the Chinese communist state but also on the moral validity of the revolution that produced it". Therefore, Deng maintained a compromise approach which emphasised both Mao's contributions and mistakes (Meisner 1999).

The new ideologies advocated by Deng were: emancipating the mind, and seeking the truth (Deng 1978). A new process of establishing hegemony in this period was launched. Deng stated that in the past, people's minds were confined within ideological taboos, the framework of phony Marxism, and that no one was allowed to go beyond this "forbidden zones" (Deng 1978). Consequently, many people had stopped questioning and innovating. However, Deng argued that this kind of thinking was not really in the spirit and principle of the CCP that he envisaged. In order to achieve the Four Modernizations, the primary task was to break down rigid thinking. In Deng's (1979) perspective, although it would take considerable time to catch up with advanced capitalist countries, capitalism could nevertheless be used to develop socialist productive forces. Although capitalism was evil, it could still be used as a technique as long as it served for socialist China. Deng (1979a, p.231 cited in Ezzamel et al. 2006) argued:

Of course we do not want capitalism, but we do not want backward and poor socialism either; we want developed socialism with high productive forces to 
make China wealthy and strong. We believe socialism is superior to capitalism. Its superiority should be manifest in it having better conditions for developing productive forces.

Although China was still a socialist country, the definition of accounting systems was changed under the impact of Deng's ideologies. Scholars incorporated the new thinking about the Chinese economy in accounting systems:

Accounting is an information system. It provides useful information through recording, measuring, analysing and examining economic activities of an enterprise as a whole, for predicting and evaluation the performance of enterprises. (Guo 1981 cited in Zhou 1988, p.215)

However, Deng's ideologies were still in the early stages of diffusion. Without a clear aim for economic reform, and a systematic approach to implement policies, the previous uniform accounting systems (before 1966) were restored in the early stage to satisfy the requirement of this economic reform. This set of accounting system still focused on meeting the macro-economic targets. More specifically, the debit-credit double entry bookkeeping method was again used in medium and large manufacturing firms, and receiptdisbursement bookkeeping method was used in small manufacturing enterprise and government agencies (Ji 2001). The accounting equation 'Fund application = Fund source' was maintained and the balance sheet was based on a principle that 'fund applications equal total fund sources'. This was considered to emphasise the socialist nature of economy, and to differentiate Chinese accounting with Western countries (Zhou 1988).

Deng and his allies believed that political reform was a necessary condition for the development of economy (Cheng 1989). It was also accepted that form of decentralisation "between the Party and the state, between the National people's Congress and the government and the economic enterprises" was necessary to enhance efficiency and to establish a clear system of accountability (Cheng 1989, p.xiii). Aiken and Lu (1993, P.117) identified different levels of authority and decentralization in the accounting discipline:

(i) Central government accounting which is conducted by the Ministry of Finance at the central level,

(ii) Provincial government accounting (in the autonomous regions and directly controlled regions) which is conducted by the financial administrative bureaux at the provincial level,

(iii) Municipal Accounting which is conducted by departments of finance at the municipal level, and

(iv) Township government accounting which is conducted by finance sections at the township level.

Some leading scholars, such as Ge, advocated that one accounting with Chinese characteristic should be established to help users understand financial statements, and help regulators enforce monitoring (Xiao et al. 2004). To establish one set of accounting became 
the most basic and essential part in the process of economic reform. Interestingly, some characteristics could be found in the draft of Chinese accounting standards, such as the legality concept and the uniformity concept. However, these characteristics were discarded when the standards were formally issued (Ji 2001).

The Chinese Accounting Standard for Enterprise was finally promulgated by the Ministry of Finance in 1992 (Ministry of Finance 1992). In contrast to the previous Uniform Accounting systems, this new accounting standards used accounting equation 'Asset = Liability + Owner's Equity' for the first time, instead of 'Fund Application = Fund Sources'. The DebitCredit double entry bookkeeping method was required to use in all enterprises. Ji (2001) argued that the harmonisation of accounting standards with western countries indicated a realisation by the public of the need to move towards internationalisation. Accounting systems were no longer influenced by the previous Soviet Union accounting, and this also shows that hegemony of Deng's capitalist ideology was achieved at the same time.

\section{Conclusion}

Gramsci's theory of hegemony explains the role of an ideology in sustaining political controls in a society. He emphasises the power of the establishment and maintenance of certain ideas and values, rather than the violence or coercive forces, in excising hegemony for the ruling parties. In this way, political control is achieved by establishing and diffusing a hegemonic culture, in which the values of the ruling class are perceived as 'common sense' among people. Gramsci also introduces a concept of organic crisis to reflect the dynamics of hegemonic changes. According to this notion, when an organic crisis occurs, the political state may reorganise institutional systems to form new ideologies which continues its hegemonic leadership.

By using Gramsci's hegemonic perspective, as Section 3 shows, the existing literature has been able to demonstrate the function of accounting in sustaining class power during this legitimisation process. This paper provides further evidence on this inter-relationship between accounting and political hegemony by exploring the accounting changes in China throughout its historical regimes. In doing so, this paper examines various accounting systems across four different periods in China: the Confucian tradition, the socialist system and the following Cultural Revolution under the Maoist era, and the socialist market system in the Dengist era. The evolutions of accounting systems are inextricably linked to these broader social and political changes in China During the early stage, the hegemonic leaders adopted Confucianism as the dominant ideology for thousands of years in ancient China, and the Confucians ideology formed the foundation of the culture that guided Chinese peoples' way of thinking during the time. This paper argues, under the significant influence of Confucianism, accounting systems closely followed Confucian principles, such as collectivism and the relative unimportance of profit, for centuries. However, while the 
ideologies of Confucianism were opposed under China's socialist system in the Maoist era, in the period following the Cultural Revolution, there were attempts to completely erase Confucian thought, which can be understood as a kind of organic change that requires an ideological shift for the ruling party.

Consequently, a new hegemonic system was being established under Mao's rule. In order to achieve a new set of common sense values, Mao sought first to align the country with Soviet allies, which saw a mirroring of accounting practices between the two communist nations. During the Cultural Revolution, Soviet accounting practices were rejected and a period followed in which the development of accounting practice completely stagnated because of its association with the evils of capitalism. The consequence of this crisis was that China's economy was directed towards capitalist systems under Deng. As such, accounting systems were firstly aligned with Western accounting systems in 1992. Thus, Gramsci's concept of hegemony provides the theoretical basis for this paper to analysing how and why the accounting systems have developed and the reasons for one economic structure being more dominant in a specific period. It is evident that China's accounting practices have been fundamentally (re)shaped by the dynamics of political ideologies as a result of ruling class trying to maintain its hegemonic leadership. 


\section{References}

Aiken, M \& Lu, W 1993, 'Chinese Government Accounting: Historical Perspective and Current Practice', The British Accounting Review, vol. 25, no. 2, pp. 109-129.

Alawattage, C \& Wickramasinghe, D 2004, 'Governance in Dialects: Their Regimes and Roles of Accounting in Sri Lanka', Fourth Asia Pacific Interdisciplinary Research Singapore, 1-36.

Alawattage, C \& Wickramasinghe, D 2008, 'Appearance of Accounting in a Political Hegemony', Critical Perspectives on Accounting, vol. 19, no. 3, pp. 293-339.

Bates, RT 1975, 'Gramsci and the Theory of Hegemony', Journal of the History of Ideas, vol. 36, no. 2, pp. 351-366.

Bing, X 1998, 'Institutional Factors Influencing China's Accounting Reforms and Standards', Accounting Horizons, vol. 12, no. 2, pp. 105-119.

Bloom, R \& Solotko, J 2003, 'The Foundation of Confucianism in Chinese and Japanese Accounting', Accounting, Business \& Financial History, vol. 13, no. 1, pp. 27-40.

Chan, L \& Rotenberg, W 1999, 'Accounting, Accounting Education, and Economic Reform in the People's Republic of China', International Studies of Management \& Organization, vol. 29, no. 3, pp. 37-53.

Chen, J-R 2007, 'Goodbay Marx Hello Confucius: Ideological Paradigm Change in Economic Transition of PRC', University of Innsbruck, Innsbruck, 1-15.

Chen, S 1998, 'The Rise and Fall of Debit-Credit Bookkeeping in China: History and Analysis', The Accounting Historians Journal, vol. 25, no. 1, pp. 73-91.

Cheng, JYS (Ed.) 1989, China's Modernization Programme in the 1980s, Introduction: China's Modernization Programme in the 1980s, The Chinese University Press, HongKong.

Chiapello, E \& Ding, Y 2004, 'Searching for the Acconting Features of Capitalism: An Illustration with Economic Transition Process in China', Accounting, auditing and Publication Siena, Italy.

Child, J \& Lu, Y 1990, 'Industrial Decision-Making under China's Reform, 1985-1988', Organization Studies, vol. 11, no. 3, pp. 321-351.

Cooper, C 1995, 'Ideology, Hegemony and Accounting Discourse: A Case Study of the National Union of Journalists', Critical Perspectives on Accounting, vol. 6, no. 3, pp. 175-209.

Dawson, R 1981, Confucius, Oxford university press, Oxford. 
Deng, X 1978, 'Emancipate the Mind, Seek Truth from Facts and Unite as One in Looking to the Future', People Daily. URL: http://english.peopledaily.com.cn/dengxp/vol2/text/b1260.html.

Deng, X 1979, 'Uphold the Four Cardinal Principles', People Daily. URL: http://english.peopledaily.com.cn/dengxp/vol2/text/b1290.html.

Ezzamel, M, Xiao, JZ \& Pan, A 2006, 'Political Ideology and Accounting Regulation in China', Accounting, Organizations and Society, vol. 32, no. 7-8, pp. 669-700.

Femia, J 1975, 'Hegemony and Consciousness in the Thought of Antonio Gramsci', Political Studies, vol. 23, no. 1, pp. 29-48.

Fu, P 1971, 'Governmental Accounting in China During the Chou Dynasty (1122 B.C.-256 B.C.)', Journal of Accounting Research, vol. 9, no. 1, pp. 40-51.

Gao, S \& Handley-Schachler, M 2003, 'The Influences of Confucianism, Feng Shui and Buddhism in Chinese Accounting History', Accounting History Review, vol. 13, no. 1, pp. 41-68.

Goddard, A 2002, 'Development of the Accounting Profession and Practices in the Public Sector - a Hegemonic Analysis', Accounting, Auditing \& Accountability Journal, vol. 15, no. 5, pp. 655-688.

Gramsci, A 1978, Selections Form the Proson Notebook Lawrence and Wishart, London.

Greaves, NM 2008, 'Intellectuals and the Historical Construction of Knowledge and Identity: A Reappraisal of Gramsci's Ideas on Leadership ', cultural logic.

Han, D. J. 2009. The History of China's Accounting Ideologies (in Chinese), Shanghai, University of Shanghai Economies.

Heidhues, E \& Patel, C 2011, 'A Critique of Gray's Framework on Accounting Values Using Germany as a Case Study', Critical Perspectives on Accounting, vol. 22, no. 3, pp. 273-287.

Ives, P 2009, 'Global English, Hegemony and Education: Lessons from Gramsci', Educational Philosohpy and Theory, vol. 41, no. 6, pp. 661-683.

Jayasinghe, K \& Matilal, S 2011, 'Accounting Calculations in Hegemonic Struggle and Popular Culture: The Case of Premiership Football in the Uk', Essex Business School Wivenhoe park, Colchester, UK 1-26.

Ji, X-D 2001, Development of Accounting and Auditing Systems in China, Ashgate publishing company, Wiltshire.

Lam, K-CJ 2003, 'Confucian Business Ethics and the Economy', Journal of Business Ethics, vol. 43 , no. 1, pp. 153-162. 
Lee, DP 2009, 'Photo-Elicitation: An Ethno-Historical Accounting and Management Research Prospect', Accounting, Auditing \& Accountability Journal, vol. 22, no. 7, pp. 1111-1129.

Lin, Z, Chen, F \& Tang, Q 2001, 'An Empirical Evaluation of the New System of Business Accounting in China', Journal of International Accounting, Auditing and Taxation, vol. 10, no. 1, pp. 23-49.

Liu, W \& Eddie, A (Eds.) 1995, Development in Accoumnting Regulation Routledge, New York.

Loftus, A \& Lumsden, F 2008, 'Reworking Hegemony in the Urban Waterscape', Transactions of the Institute of British Geographers vol. 33, no. 1, pp. 109-126.

Loftus, A \& Lumsden, F 2008, 'Reworking Hegemony in the Urban Waterscape', Transactions of the Institute of British Geographers, vol. 33, no. 1, pp. 109-126.

Meisner, M 1999, Mao's China and After, The free press, New Your.

Merino, BD, Mayper, AG \& Tolleson, TD 2010, 'Neoliberalism, Deregulation and SarbanesOxley: The Legitimation of a Failed Corporate Governance Model', Accounting, Auditing \& Accountability Journal, vol. 23, no. 6, pp. 774-792.

Ministry of Finance 1992, 'Accounting Standards for Enterprises', Chinese Economy and Finance Publishing.

Momin, M \& Belal, AR 2009, 'The Views of Selected Ngos on Corporate Social Disclosures in Bangladesh', Ninth Interdisciplinary perspective on accounitng Innsbruck, Australia 1-34.

Pun, SH 1996, 'Hegemonic Struggles in the Language Policy Development of Hong Kong, 1982-1994', Asia Pacific Journal of Education, vol. 16, no. 1, pp. 88-105.

Pye, LW 1985, Asian Power and Politics: The Cultural Dimensons of Authority, The Belknap press of Harvard University Press, London.

Richardson, AJ 1987, 'Accounting as a Legitimating Institution', Accounting, Organizations and Society, vol. 12, no. 4, pp. 341-355.

Rucki, S 2011, 'Global Economic Crisis and China's Challenge to Global Hegemony: A NeoGramscian Approch', New Political Science, vol. 33, no. 3, pp. 335-355.

Schoppa, RK 2011, Revolution and Its Past: Identities and Change in Modern Chinese History Pearson Education, Upper Saddle River.

Simon, R 1982, Gramsci's Political Thought, Lawrence and Wishart London.

Solas, C \& Ayhan, S 2007, 'The Historical Evolution of Accounting in China: The Effects of Culture', Spanish Journal of Accounting History, pp. 146-173. 
Spence, C 2009, 'Social Accounting's Emancipatory Potential: A Gramscian Critique', Critical Perspectives on Accounting, vol. 20, no. 2, pp. 205-227.

SUFE \& CIAD 1987, Accounting and Auditing in the People's Republic of China: A Review of Its Practices, Systems, Education and Developments, Centre for International Accounting Development: The university of Texas at Dallas, Texas.

Tang, Y 1997, 'The Recent Accounting Development and Internationalization of Accounting Education in China', Issues in Accounting Education, vol. 12, no. 1, pp. 219-229.

Tao, D. 1951. 'Reading of "How to Construct new China's Theoretical Basis in Accounting System"' (in Chinese). New Accounting, vol. 4, pp. 14-15.

Thornton, RC 1982, China: A Political History, 1978-1980, Westview Press, Colorado.

Van Hoepan, M (Ed.) 1995, Perspectives on Accounting and Finance in China, Accounting in China: A Case of Vanishing Cultural Influence, Routledge, London.

Williams, GA 1960, 'The Concept of 'Egemonia' in the Thought of Antonio Gramsci: Some Notes on Interpretation', Journal of the history of ideas, vol. 21, no. 4, pp. 586-599.

Winkle, GM, Fenwick Huss, H \& Chen, X-Z 1994, 'Accounting Standards in the People's Republic of China: Responding to Economic Reforms', Accounting Horizons, vol. 8, no. 3, pp. 48-57.

Xiao, J, Weetman, P \& Sun, M 2004, 'Political Influence and Coexistence of a Uniform Accounting System and Accounting Standards: Recent Developments in China', Abacus, vol. 40, no. 2, pp. 193-218.

Xin, Z \& Huang, S 1951, 'How to Construct New China's Theoretical Basis in Accounting System (in Chinese)', New Accounting vol. 1, pp. 12-16.

Yan, J \& Gao, G 1996, Turbulent Decade: A History of the Cultural Revolution, University of Hawaii Press, Hawaii.

Yang, Y 1974, Confucius: "Sage" Of the Reactionary Classes, Foreign Languages Press, Peking.

Yee, $\mathrm{H}$ 2009, 'The Re-Emergence of the Public Accounting Profession in China: A Hegemonic Analysis', Critical Perspectives on Accounting, vol. 20, no. 1, pp. 71-92.

You, J \& Luo, S 2009, 'Accounting Internationalization and Value Relevance of Accounting Earnings in China', Frontiers of Business Research in China, vol. 3, no. 2, pp. 171-189.

Zhang, G 2005, 'Environmental Factors in China's Financial Accounting Development since 1949', Erasmus University Rotterdam, Rotterdam.

Zhang, T \& Schwartz, B 1997, 'Confucius and the Cultural Revolution: A Study in Collective Memory', International Journal of Politics, Culture, and Society, vol. 11, no. 2, pp. 189-212. 
Zhou, Z 1988, 'Chinese Accounting Systems and Practices', Accounting, Organizations and Society, vol. 13 , no. 2, pp. 207-224. 